\title{
Modelling University Business Incubator for SMEs Digitalisation
}

\author{
N Huda ${ }^{* 1}$, C Rejito ${ }^{2}$ \\ ${ }^{1}$ Department of Industrial Engineering, Universitas Ahmad Dahlan, Yogyakarta, \\ Indonesia \\ ${ }^{2}$ Department of Management, Universitas Padjajaran, Sumedang, Indonesia
}

E-mail: nisrina.huda@ie.uad.ac.id ${ }^{1}$, cattleya12001@mail.unpad.ac.id ${ }^{2}$

Submitted: 13 July 2020, revised: 17 August 2020, accepted: 19 August 2020

\begin{abstract}
Abstrak. Program inkubasi bisnis merupakan salah satu strategi yang beberapa tahun terakhir semakin banyak diadopsi oleh perguruan tinggi untuk melakukan proses transfer ilmu guna menopang UMKM. Namun studi yang berfokus pada modeling universitas inkubator bisnis yang khusus melayani UKM masih jarang. Riset mengenai inkubator bisnis saat ini didominasi oleh riset yang terkait dengan start-up dan perusahaan berbasis teknologi baru, yang memiliki karakter dan kebutuhan berbeda dari UKM. Oleh karena itu, penelitian ini dilakukan untuk mengembangkan model konseptual inkubator bisnis perguruan tinggi dengan tujuan utama membantu para pelaku UKM dalam mendigitalkan bisnis yang mereka jalankan. Melalui metode studi literatur diperoleh model inkubator bisnis perguruan tinggi yang terdiri dari empat komponen yaitu preparasi, pra inkubasi, inkubasi, dan pasca inkubasi. Salah satu bagian yang sangat membedakan model yang dibangun dalam penelitian ini dengan pendahulunya terletak pada proses pendidikan selama proses inkubasi. Proses pendidikan akan dilakukan dengan mengundang tenant pada kuliah umum dan seminar yang membahas materi terkait yang diadakan oleh universitas pengelola inkubator.
\end{abstract}

Kata kunci: inkubasi bisnis; model inkubator bisnis; inkubator bisnis universitas; UKM; digitalisasi

\begin{abstract}
Business incubation program is one strategy that in the recent years has been increasingly adopted by universities to carry out the knowledge transfer process in order to sustain SMEs. However, studies that focus on modelling university business incubator which specializes in serving SMEs are still rare. Current research on business incubators is dominated with research that links to start-up and new technology-based firm, which have different characters and needs from SMEs. Therefore, this research was conducted to develop a conceptual model of university business incubator with the main objective of helping the SMEs to digitize the business they run. Through literature study method, this study obtained a university business incubator model consisting of four components namely preparation, preincubation, incubation, and post-incubation. One part that really differentiates the model built in this study with its predecessors lies on the education process during the incubation process. The
\end{abstract}


educational process would be carried out by inviting tenants in general lectures and seminars discussing related material held by the university managing the incubator.

Keywords: business incubation; business incubator model; university business incubator; SMEs; digitalisation

\section{Introduction}

It has been revealed since many years ago that Small and Medium Enterprises (SMEs) play an important role in the nation's economy, including Indonesia. This is because they are flexible, innovative and can generate income [1]. In accordance with the amount, which reached 64.2 million in 2018, to date SMEs still dominate the total enterprises in Indonesia with a percentage of $99.9 \%$, where the remaining $0.01 \%$ is occupied by large companies. By its huge number, [2] mentioned that the potential of SMEs in creating employment has been able to achieve $97.16 \%$, while its contribution to GDP is able to achieve $58.65 \%$. Other than that, SMEs are also able to reduce poverty, ensuring equitable development, and ensuring sustainable development.

On the other hand, the world countries have been entering a new phase named the digital economy, which is defined as the economy that working on electronic goods and services, dispatching e-business and e-commerce, and also utilizing e-money [3]. The proliferation of the digitalization process and the rapid development of information and communication technology to become a lifestyle have certainly influenced the overall value chain of a business [4]. Information technology can support the steps of business processes, such as product orders and division of tasks to the right people [5]. Besides, a study by [6] has summarized the impact of digitalization, specifically the use of social media on the sales process in SMEs such as build a corporate brand [7], improve market and sales [8, 9], attract new customers [8, 10], build a network of companies [11] and so on.

However, the use of information technology remains a challenge for SMEs where many SMEs owners still imply that their companies have not fully utilized information technology [12]. Compared to large companies, decision-making on information technology utilization in MSMEs focuses more on short-term planning [13]. The Ministry of Cooperatives and Small and Medium Enterprises reported that there are currently only $8 \%$ of the total SMEs in Indonesia which have utilized online platforms in marketing their products [14]. The lack of technology adoption and implementation at MSMEs is caused by many barriers. A study in United Kingdom [15] has summarized and analysed ten factors that inhibit technology adoption, especially m-commerce adoption in SMEs, namely perceived cost, perceived risk, lack of technology knowledge, changes in business strategy and processes, lack of customer trust and confidence, unawareness of benefits, inconvenience of use, lack of external pressure, compatibility issues, and privacy and security issues.

The low ability of SMEs to adopt technology becomes complicated when the COVID-19 virus appears at the end of 2019 and WHO declared it as a global pandemic on 11 March 2020 [16]. In a very short period, this pandemic caused massive changes in various aspects of life, especially after WHO encouraged the public to do physical distancing. Stay-at-home and go-virtual lifestyle inevitably happened and forced industries, including SMEs, to change their business processes in order to fit their consumer behaviour shifting. According to [17], this condition has jump-started a wave of digitalisation which can go two ways: the sustainable and integrated digital transformation, or the dangerous path of turning non-digital enterprises into minimally skilled end-users of information technology products and services. Therefore, collaborative efforts from various parties are needed to move the condition toward a better direction.

Universities, through its richness of research, have become an important component that cannot be ignored in the country's economic development process and competitiveness [18]. They are expected to be able to generate innovations and high-quality human resources and to shape a great impact on 
civilization. Universities are also believed to be the agents of knowledge and technology transfer to both academic and non-academic parties where the process can be done through plentiful ways and strategies. The incubation, especially business incubation program, is one strategy that in recent years has been increasingly adopted by universities to carry out the knowledge transfer process in order to sustain SMEs. University Business Incubators (UBI) have very high flexibility regarding the models and services that they provide to SMEs who act as their tenants. However, studies that focus on modelling university business incubator which specializes in serving SMEs are still rare. Most of the studies discussing university business incubator today are still dominated with research that links it to start-up and new technology-based firm (NTBF), which have different characters and needs from SMEs. Thus, this research is conducted in order to propose a conceptual model of university business incubator which specializes in fostering SMEs digitalisation.

\section{Research Methodology}

In this study, literature study method is adopted to achieve the main objective of the study, which is to design a business incubator model in tertiary institutions with tenant targets limited to SMEs. The literature study method is divided into two stages as shown in Figure 1.

In stage I, the literature study process is divided into two stages which are carried out sequentially. The first part is done to analyze the background of the problem, while the second part is done to explain some related things that are useful in bridging the problem with the solution or research objectives to be achieved.

The stage II literature study process is carried out for the purposes of research methodology and the achievement of research objectives which will later be described in Section 3. Based on the background of the problem and the research objectives described in the previous section, this research is conducted as a form of contribution and efforts to help the SME actors who have been "forced" to change their processes and business models online since the pandemic. The literature study process at this stage is divided into two major themes, namely the business incubator of higher education and the digitalization of SMEs. For the university business incubator theme, the study of literature was conducted by searching for four keywords, namely Business Incubation, University Business Incubator, University Business Incubat* Model, and Technology Transfer from University to Small Business. The use of an asterisk in one of the keywords is done so that the search results include the words "incubation" or "incubator" [19]. For the theme of digitizing MSMEs, one keyword is used in the reference search process, namely SME Digitalization. 


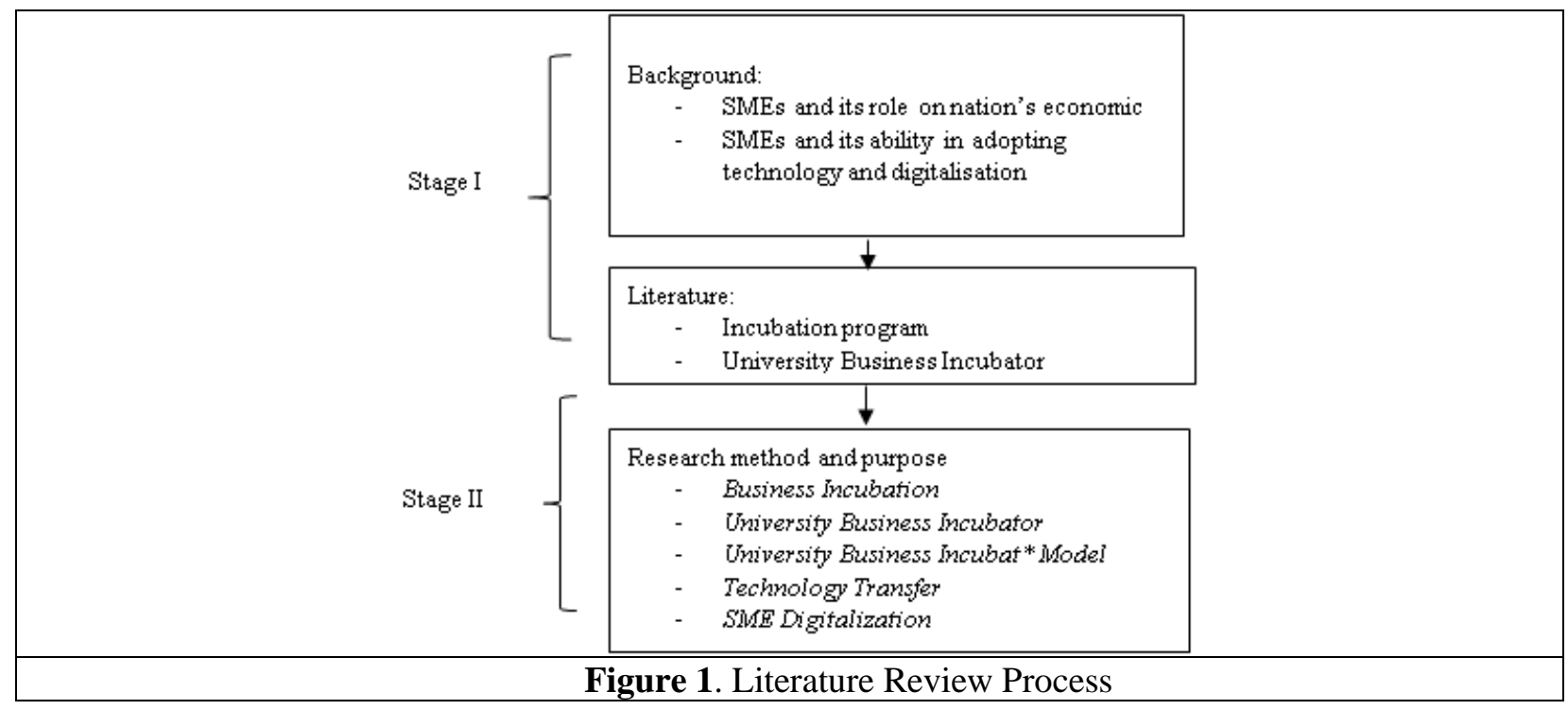

The process of article references searching starts with entering the keywords that have been mentioned above on one of the scientific search engines such as scopus.com. The results obtained from the searching process are then extracted through 3 stages, which are:

1) Initial references: Articles obtained after entering keywords.

2) Limited references (candidates): Articles obtained after filtering are as follows: a. Access Type: Open Access; b. Document Type: Article \& Conference Paper; c. Source Type: Journal \& Conference Proceeding

3) Selected references: Articles that have successfully passed stage 2 of the extraction process are then declared in accordance with research needs through a screening process in the abstract section, methodology, and research results.

A diagram which explains the process of the systematic literature review process is presented in Figure 1, while the number of articles at each extraction stage can be seen in Table 1.

Table 1. Data Extraction

\begin{tabular}{|c|c|c|c|c|c|c|}
\hline \multirow[b]{2}{*}{ Keywords } & \multirow[b]{2}{*}{ Initial } & \multicolumn{4}{|c|}{ Candidate } & \multirow[b]{2}{*}{ Selected } \\
\hline & & $\begin{array}{c}\text { DT- } \\
\text { A }\end{array}$ & $\begin{array}{l}\text { DT- } \\
\text { C }\end{array}$ & $\begin{array}{l}\text { ST- } \\
\text { J }\end{array}$ & $\begin{array}{l}\text { ST- } \\
\text { C }\end{array}$ & \\
\hline Business Incubation & 5509 & 76 & 9 & 78 & 7 & 21 \\
\hline University Business Incubator & 443 & 46 & 4 & 47 & 3 & 8 \\
\hline University Business Incubat* Model & 157 & 19 & 2 & 20 & 1 & 13 \\
\hline $\begin{array}{l}\text { Technology Transfer from University to Small } \\
\text { Business }\end{array}$ & 237 & 10 & 5 & 11 & 4 & 12 \\
\hline SME Digitalization & 167 & 27 & 23 & 24 & 16 & 10 \\
\hline
\end{tabular}

Notes:

DT-A : Document Type - Article

DT-C : Document Type - Conference Paper

ST-J : Source Type - Journal 
Vol. 3, No. 1, August 2020

ST-C : Source Type - Conference Proceeding

\section{Result and Discussion}

\subsection{Definition of Business Incubator}

One interesting issue relating to business incubators that have been widely discussed in recent years is that there is no universal definition of business incubators themselves [19,20] despite the many definitions. The issue of difficulties and the absence of a universal definition related to business incubators have even occurred in the past two decades. From this condition, researchers conducted a systematic and comprehensive literature review to formulate a universal definition related to business incubators. In this study, the definition of business incubator refers to the definition in the academic context put forward by [21], which is "an organization that facilitates the process of creating successful new small enterprises by providing them with a comprehensive and integrated range of services, including professional management, which involves monitoring tenant businesses closely against their business plans and ensuring that the incubator itself operates in a business-like fashion with the prospect of becoming financially self-sustaining". The use of definition by [21] as a reference is based on the fulfilment of all organizational components in the theory that put forward by [22] such as a multi-agent system, identifiable boundaries, system-level goals, dan constituent agent's effort are expected to make a contribution. Through this definition, the university business incubator of this study is not just a program or project but is a form of organization.

\subsection{The Types of Business Incubator}

In the early days of its emergence, business incubators consisted of only two types, namely the private incubator that was first established in New York in 1959 [23] and the public incubator that first operated in Philadelphia in 1964 [24]. The differences in sponsors that form the basis for the birth of the two types of business incubators indirectly also affect the different goals of each business incubator. Public incubators receive funding from the government so that one of its main objectives is to help the government improve economic conditions, one of which is by providing employment. Meanwhile, private incubators are funded by private parties or companies. So, the main goal is focused on two things, namely the achievement of Return on Investment (ROI) and financial success of tenants [19].

Furthermore, the two types of business incubators continue to branch out to produce new types of business incubators as more and more sponsors are involved in their establishment and management. Scientifically, the type of business incubator was first divided into four types, namely public incubator, non-profit incubator, university incubator, and private incubator [25]. Slightly different, [20] distinguishes incubators into two types namely for-profit and non-profit incubators. Whereas [26], [27], and [28] mentioned more types of business incubators namely technology incubators, university incubators, independent incubators, virtual incubators, regional incubators, and innovation center. Moreover, [29] differentiates business incubators into five types based on competitive advantage and strategic objectives, including university incubators, regional incubators, virtual incubators, independent commercial incubators, and internal-corporate incubators. In addition, [30] distinguishes business incubators into two types based on their institutional mission. The first type is the innovation center and regional public incubator, while the second type is the private incubator. The position of the university business incubator is between them [30]. With this position, the main objective of the establishment of university business incubators is not only to fulfil the government's mission in terms of the economy, but also to transfer technology, promote the field of entrepreneurship, and commercialize the research produced at the university [31]. The university business incubator in this study is defined as a business 
incubator designed by the university to provide tangible and intangible services to help the business continuity of a new business.

\subsection{Business Incubator Models}

Along with its development, the current business incubator model is increasingly diverse due to the influence of various factors such as sponsors and goals. In its design, [32] mentioned 4 important components in the business incubator model, namely entry criteria, selection process, funding, and mentoring networking. Three years later, the model was developed into 5 components which sequentially consisted of the incubation candidate pool munificence, selection of performance, resource munificence, monitoring \& business assistance intensity, and outcomes [33]. The next model was designed by [34] which consisted of 3 components, namely pre-incubation, entry criteria \& selection process, and monitoring \& controlling. Other researchers [35] model this business incubator with 3 basic components, namely pre-incubation (input), incubation (process), and graduation (output). The two newest models proposed by [20] and [36] consist of 4 components which are not much different from previous models, namely selection, process, graduation, mediation and preparation, pre-incubation, incubation and post incubation.

Although the various components and stages of the incubator model do not look very different from one another, the technical details of implementation at each stage are very diverse. An example is the implementation details at the stage of the selection process and the criteria for accepting prospective tenants. In this process, there is an incubator which determines that the accepted tenants are homogeneous ones, so that the incubator can arrange specific plans, targets, and networks [28,37]. In the contrary, there are also incubators who accept tenants with diverse or heterogeneous backgrounds in the context of the value chain and life-cycle stage [38] in the hope of cross-fertilization between tenants [39]. The difference at the initial stage will have an impact on the next stages, including the services provided later.

\subsection{Business Incubator's Types of Services}

Previous studies have shown how business incubators continue to develop and transform over time, not only in terms of numbers, but also in terms of definition, goals, and sponsors and tenants involved. A study by [19] succeeds in summarizing the various definitions of business incubators from 1985 to 2012 which then indicate changes in service trends provided by business incubators. Business incubators that initially focused on providing services in physical facilities such as shared offices, have in recent years begun to shift towards providing intangible services $[19,40]$ in the form of consultations, training, seminars, and others. In line with this, a study by [20] states that business incubators today tend to focus their services on providing added value, namely specific ways to improve the ability of tenants so that businesses can continue to grow and survive [41]. This is packaged in the form of development, acceleration, and assistance to tenants through the process of coaching, networking access, business advisory and training [20].

The types of services provided by various business incubators can be seen in Table 2 .

Table 2. Business incubators' services

\begin{tabular}{cl}
\hline References & \multicolumn{1}{c}{ Business Incubators' Services } \\
\hline$[20]$ & a) Coaching (training \& educational workshop) \\
& $\begin{array}{l}\text { b) Networking (access to various consultants and social networks) } \\
\text { c) Seminar }\end{array}$
\end{tabular}

Huda, Rejito (The Modelling University Business Incubator for SMEs Digitalisation) 


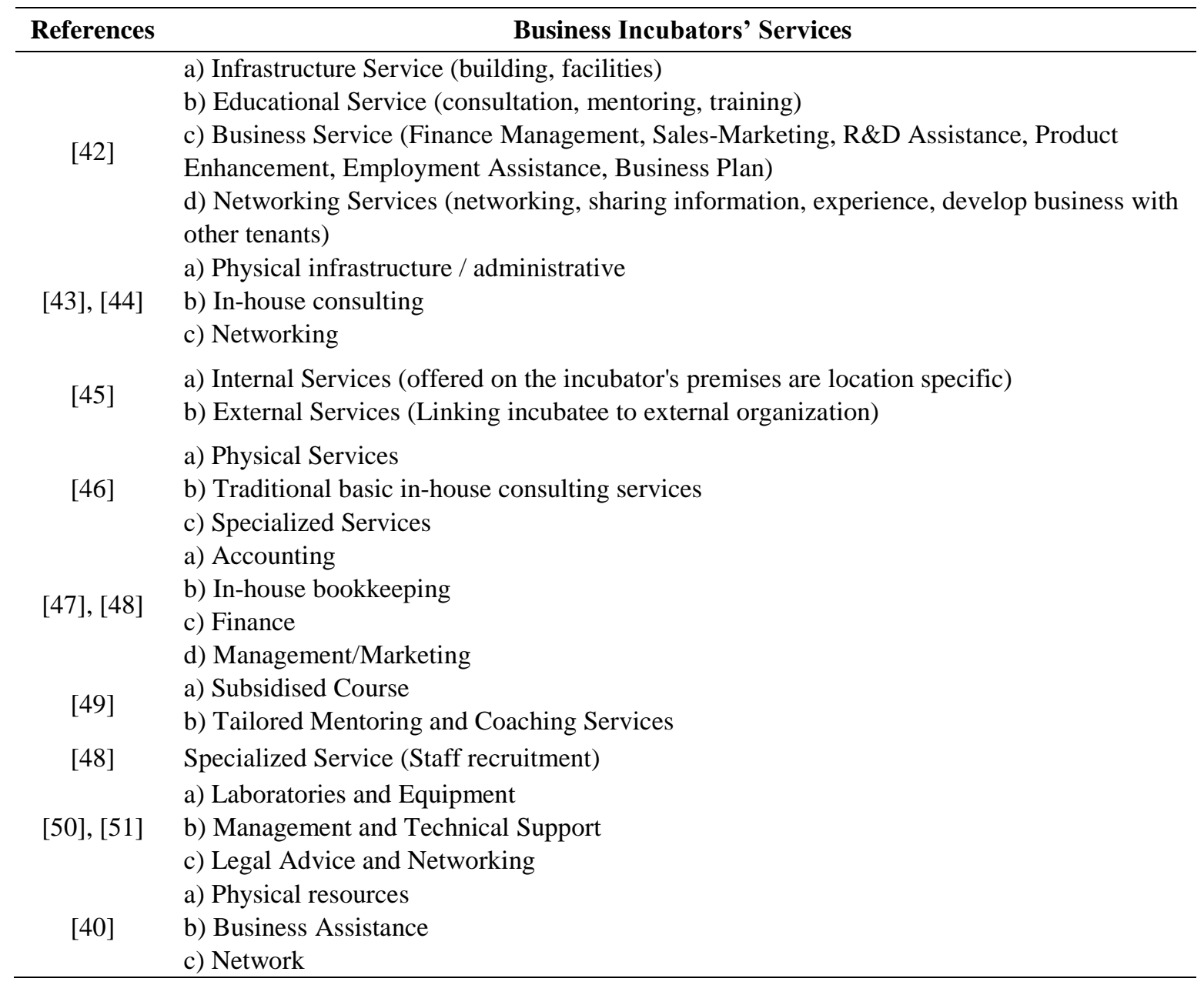

\subsection{The Digitalization of SMEs}

Digitalization or transformation is defined as the process of adopting and using digital technology in individual, organizational, and social contexts [52]. A study by [53] describes that digitalization is basically not about technology, but about strategy. Not much different, [54] and [55] say that digital transformation is not about optimizing internal processes or technology integration processes, but fundamentally changing the business model as well as how MSMEs create and capture certain values. On the other hand, [56] state that digital transformation is multi-disciplinary because it involves changes in strategy, organization, information technology, supply chain, and marketing. Likewise, with [57] and [58], both reveal that digital transformation is a learning process that requires the integration of technology, business, and learning strategies in entrepreneurial oriented organizations. More specifically, digitalization is said to be a socio-technical process [59,60]. In addition, digitalization is also said to require a combination of various complementary resources [61].

The involvement of many parties and components in the implementation process, it can be said that digital transformation or digitalization has its own complexities and challenges. [62] state that doing digital transformation at the organizational level is the same as making changes to the beliefs, norms, and behaviour of a group of people in the organization, so the process tends not to be easy and is often followed by difficulties and rejection. Another source [63] also convey the same thing that digitizing is 
a difficult transformation, especially with various changes such as changes in structure, replacement and procurement of things to complement the ongoing process, as well as new strategic objectives.

Realizing this condition, some researchers conducted a study to find out the factors that were the key to success and obstacles in implementing digitalization, where the results could be utilized by the implementers to design strategies and anticipatory steps needed. Some things that according to research [64] need to be anticipated because they are often a limiting factor in the process of digital transformation and technology adoption, namely: (1) ignorance of technology, lack of expertise, incompatibility, confusing ROI, implementation and maintenance costs, and user resistance; (2) security issues, lack of time, lack of use in the working partners' environment, access, integration, updates, and reliability. On the other hand, there are many keys to success in the implementation of digitalization that we can pay attention to, among other things are complementary knowledge-based assets such as organizational \& human capital [65], and a supportive environment, where a company or organization can take advantage full of technology, including teamwork and stronger leadership [66] [58]. In addition, MSMEs also require a combination of hard skills (the ability to use technology and analyze large amounts of data) and soft skills (generating ideas and capturing opportunities) to achieve successful digital transformations that they do [67] [68]. In addition, a study [69] outlines several factors that can encourage growth through the digitization process, including: (1) equating perceptions about "digitally possible growth"; (2) increasing the understanding of MSME actors and the people involved in it regarding the need for capabilities, opportunities, and threats; and (3) developing and communicating strategies. In addition, [68] mentions some important skills needed in this digital era, namely: (1) critical thinking and problem solving; (2) collaborating on a network and leading with influence; (3) flexibility and adaptability; (4) initiative and entrepreneurial spirit; (5) effective oral and written communication; (6) evaluates and analyzes information; and (7) curiosity and imagination.

\subsection{University Business Incubator Model for SMEs Digitalization}

After comparing and analyzing the various components of the model mentioned, this study proposes business incubator of the university that is divided into 4 stages, namely the preparatory, pre-incubation, incubation, post-incubation phases with the following details:

1) Preparation: This stage is the preparation stage, where the university carries out a strategic development process with the following steps:

- Market Need, including setting the limitation of targeted tenants

- Stakeholder Values, including determining sponsors and parties who will be involved in managing the university's business incubator in the future, as well as gaining commitment from each stakeholder.

- Mission and Purpose, including in explaining the mission, main objectives of the business incubator, and plans for its achievement. This becomes one of the important steps because the position of the university business incubator is between the public incubator and private incubator. Consequently, the mission and objectives that are owned need to be well designed so that they are able to accommodate the needs of the government as well as the private and independent parties involved in it.

- Organizational Design and Governance, including designing organizational structures and rules that apply.

- Facilities and Services, including determining which facilities and services and access given to incubation tenants. This is done by considering the results of the previous four steps.

- Staffing, this step is a step in preparing the formation of administrative staff, both administrative and professional staff. In this section, it is hoped that university business incubators utilize internal resources such as students, researchers, and others. 
- Business plan detailing, this is related to the position of the university business incubator that contains elements of private incubator so that it is very much needed a business scheme to be carried out, particularly related to the process of commercialization and monetization.

- Network Development, including building public awareness with the wider community and prospective tenants, also building relationships with related parties who involve in providing services to tenants

- Economic Impact, determining the metrics or indicators that are used to measure the success of the university's own business incubator.

2) Pre-incubation: This is the stage of preparing prospective tenants which consists of 2 stages:

- Entry \& Exit Criteria. The determination of entry and exit criteria is carried out by considering the values of the stakeholders as well as the mission and objectives of the university business incubator that have been agreed upon at the preparation stage.

- Selection Process.

3) Incubation: This stage is the core part of the process and services provided to tenants. In the university business incubator model proposed in this study, the processes and services provided are designed by considering the needs of digitizing SMEs as well as the capabilities of university business incubators, namely:

- Initiation. The first thing to do at incubation is to introduce the environment, resources and networks owned by the university's business incubator to SMEs as tenants in the university business incubator. In addition, MSMEs are also given knowledge related to the mission and objectives of the university business incubator as well as the road map of the incubation process that they will go through later.

- Education. One of the factors that hinders the smooth process of digitization is the ignorance of technology and matters related to digitization. Therefore, the first service provided at the incubation stage is to provide basic knowledge to tenants about digitalization, specifically covering 4 main areas namely administrative digitalization, marketing digitalization, sales digitization, service digitalization [70]. This service is beneficial to overcome the conditions of many SMEs that are confused about two things, namely when to start and what to do to start the digitization process. In addition, referring to the number of references that link the digitization process with changes in the business model, then at this stage the tenants will also be given basic knowledge related to the business model and how to arrange it. Aside from being held at special sessions, this education service can be carried out by inviting tenants in general lectures and seminars containing related material held by the university managing the incubator.

- Consultation-Mentoring - Coaching -Controlling. Unlike the previous service which was carried out together in a large forum, in this service each tenants had the opportunity to conduct a series of in-depth consultations-mentoring-coaching individually, under the supervision of professionals who were assigned to assist and guide.

- Network Development. One important factor in the incubation process is the capability of the incubator to connect the network it has built with tenants [71][72][73] [74][75][76][77]. Referring to [78], the university is a liaison actor in a triple-helix structure consisting of government, businesspeople, and academics. Then, at this step the university business incubator should be able to connect tenants with the three parties. Building a good relationship between tenants and the university is very beneficial considering the university has very broad access to human resources that continue to be renewed every year [79][80]. The university business incubator is also expected to be able to connect tenants with angel \& venture capital investors. In addition, not less important, university business incubators are expected to be able to build a supportive environment for the tenants to synergize with internal networks, such as fellow tenants. 
- Graduation. This stage will be reached when the tenants have met the targets agreed with the university business incubator from the start.

4) Post Incubation: This stage is the stage after a tenant is declared to graduate from the university business incubator shelter. The relationship between tenants and incubators is expected to continue to be established in the form of a network, for the purposes below:

- Evaluation. This step is carried out to measure and evaluate the performance of tenants who have graduated from university business incubators and run their businesses independently.

- Incubator Re-definition. This step is carried out by collecting testimonies from tenants who have graduated from the incubator related to the incubation process they have lived. The testimonials are then processed as material to redefine and improve the quality of university business incubators.

- Alumni community. The development of the alumni community is very important to expand the network of fellow alumni and between alumni and tenants who are undergoing the incubation process.

The university business incubator model for digitizing SMEs can be seen in Figure 2.

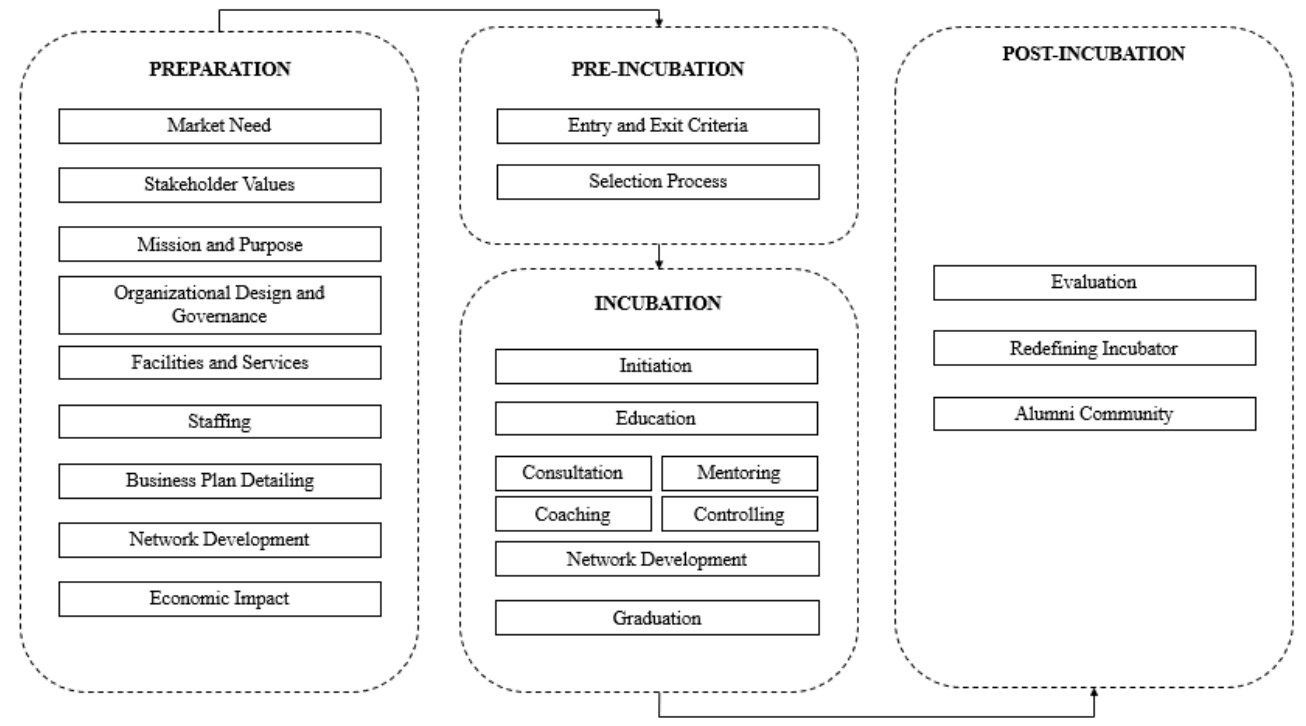

Figure 2. University Business Incubator Model for SMEs Digitalization

\section{Conclusion}

SMEs has a very important role as a catalyst for the economy in Indonesia. On the other hand, with the existence of this pandemic, MSMEs are becoming one of the business units that has been badly hit because there are still many SMEs doing business processes non-digitally. So, when human mobilization is limited, SMEs inevitably have to carry out business transformation to run the wheels of the economy. However, the problem that then arises is that the process of digital transformation of SMEs cannot run instantly. Many resources, both in the form of capital and humans, are not yet owned by SMEs so that SMEs cannot transform well.

Universities, on the other hand, have a business incubator that serves as a forum for developing digital-based businesses. Universities in this condition can be a catalyst for the transformation of SMEs towards digitalization so that SMEs can still survive in this era of economic recession and can develop their businesses in the long run. The role of the university as a center of knowledge can be an added value for SMEs in order to collaborate with digital tenants which are currently being developed by 
universities. This idea is in line with the objectives of this research that is to collaborate universities and SMEs in the process of digital transformation.

The digital transformation process by universities for SMEs is divided into 4 phases or stages adopted from the business incubator model initiated by previous studies from various universities in the world. It is hoped that the digital SME transformation model carried out by the university can lead SME to digital business process. Not only can SME growth improve the nation's economy, but also have positive impact on the growth of global economy.

\section{References}

[1] Taylor, P. (2019). Information and Communication Technology (ICT) adoption by small and medium enterprises in developing countries: The effects of leader, organizational and market environment factors. International Journal of Economics, Commerce and Management United Kingdom, 7(5)

[2] I Wayan Dipta. (2017). ILO/OECD Workshop for Policy Makers on Productivity and Working Conditions in SMEs.

[3] Berdykulova, G. M. K., Sailov, A. I. U., Kaliazhdarova, S. Y. K., \& Berdykulov, E. B. U.(2014). The emerging digital economy: case of Kazakhstan. Procedia-Social and Behavioral Sciences, $109,1287-1291$.

[4] Watanabe, C., Naveed, K., Tou, Y., \& Neittaanmäki, P. (2018). Measuring GDP in the digital economy: Increasing dependence on uncaptured GDP. Technological Forecasting and Social Change, 137, 226-240.[5] Nurmadewi, D., \& Er, M. (2019). Analyzing Linkage Between Business Process Management (BPM) Capability and Information Technology:A Case Study in Garment SMEs. Procedia Computer Science, 161, 935-942. doi:10.1016/j.procs.2019.11.202

[5] Wardati, N. K., \& Er, M. (2019). The Impact of Social Media Usage on the Sales Process in Small and Medium Enterprises (SMEs): A Systematic Literature Review. Procedia Computer Science, 161, 976-983. doi:10.1016/j.procs.2019.11.207

[6] Andersson, Svante, and Niclas Wikström. (2017) "Why and How are Social Media Used in a B2B Context, and Which Stakeholders are Involved?" Journal of Business \& Industrial Marketing 32 (8): 1098-1108.

[7] Virtanen, Henrik, Peter Björk, and Elin Sjöström. (2017) "Follow for Follow: Marketing of a Start-Up Company on Instagram.” Journal of Small Business and Enterprise Development 24 (3): 468-484.

[8] Shemi, Alice P., and Chris Procter. (2018) "E-commerce and Entrepreneurship in SMEs: Case of myBot." Journal of Small Business and Enterprise Development 25 (3): 501-520.

[9] Pongpaew, Wimmala, Mark Speece, and Leela Tiangsoongnern. (2017) "Social Presence and Customer Brand Engagement on Facebook Brand Pages." Journal of Product \& Brand Management 26 (3): 262-281.

[10] Drummond, Conor, Helen McGrath, and Thomas O'Toole. (2017) "The Impact of Social Media on Resource Mobilisation in Entrepreneurial Firm." Industrial Marketing Management 70: 6889.

[11] Annisa, L. H., \& Er, M. (2019). Impact of Alignment between Social Media and Business Processes on SMEs' Business Process Performance: A Conceptual Model. Procedia Computer Science, 161, 1106-1113. doi:10.1016/j.procs.2019.11.222

[12] Levy, Margi, and Philip Powell. (2002) "SME Transformation: Modelling Progressions", in 10th European Conference on Information Systems and the Future of the Digital Economy (ECIS), Polandia. pp. 676-685. 
[13] Kustin Ayuwuragil, S. (2017). CNN Indonesia. Available from: https://www.cnnindonesia.com/ekonomi/20171115161037-78-255819/kemenkop-ukm-379-jutaSMEs-sudah-go-online

[14] Rana, N. P., Barnard, D. J., Baabdullah, A. M., Rees, D., \& Roderick, S. (2019). Exploring barriers of $\mathrm{m}$-commerce adoption in SMEs in the UK: Developing a framework using ISM. International Journal of Information Management, 44, 141153.doi:10.1016/j.ijinfomgt.2018.10.009

[15] WHO. 26 March 2020. Critical preparedness, readiness and response actions for COVID-19

[16] Digital SME Alliance. 7 May 2020. Covid-19 Economic Recovery: A Recovery Strategy Building On Digital

[17] Wonglimpiyarat, J. (2016). The innovation incubator, university business incubator and technology transfer strategy: The case of Thailand. Technology in Society, 46, 18-27. doi:10.1016/j.techsoc.2016.04.002

[18] Hausberg, J. P., \& Korreck, S. (2020). Business incubators and accelerators: a co-citation analysis-based, systematic literature review. The Journal of Technology Transfer, 45(1), 151-176.

[19] Towards a New Perspective on the Heterogeneity of Business Incubator-Incubation Definitions. Sarah Al Ayyash , Maura McAdam, and Colm O'Gorman.

[20] O. Adegbite, “Journal search results," Small Bus. Econ., vol. 17, no. 3, pp. 157-166, 2001. doi: 10.1023/a:1011801018398.

[21] P. Puranam, O. Alexy, and M. Reitzig, "What's "New" about new forms of organizing?" Acad. Manag. Rev., vol. 39, no. 2, pp. 162-180, 2014. doi: 10.5465/amr.2011.0436.

[22] Lewis, D. A. (2001). Does technology incubation work? A critical review. In Reviews of Economic Development Literature and Practice No. 11, 48 p.

[23] Campbell, C., \& Allen, D. N. (1987). The small business incubator industry: Micro-level economic development. Economic Development Quarterly, 1(2), 178-191.

[24] Kuratko, D. F., \& LaFollette, W. R. (1987). Small business incubators for local economic development. Economic Development Review, 5(2), 49.

[25] R. Aernoudt, "Incubators: Tool for entrepreneurship?" Small Bus.Econ., vol. 23, no. 2, pp. 127 135, 2004. doi: 10.1023/b:sbej.0000027665.54173.23.

[26] Clarysse, B., Wright, M., Lockett, A., Van de Velde, E., \& Vohora, A. (2005). Spinning out new ventures: a typology of incubation strategies from European research institutions. Journal of Business venturing, 20(2), 183-216.

[27] European research institutions," J. Bus. Venturing, vol. 20, no. 2, pp. 183-216, 2005. doi: 10.1016/j.jbusvent.2003.12.004.

[28] D. Tranfield, D. Denyer, and P. Smart, "Towards a methodology for developing evidenceinformed management knowledge by means of systematic review," Brit. J. Manage., vol. 14, no. 3, pp. 207-222, 2003. doi: 10.1111/1467-8551.00375.

[29] Von Zedtwitz, M. (2003). Classification and management of incubators: Aligning strategic objectives and competitive scope for new business facilitation. International Journal Entrepreneurship and Innovation Management, 3, 176-196.

[30] Grimaldi, R., \& Grandi, A. (2005). Business incubators and new venture creation: an assessment of incubating models. Technovation, 25(2), 111-121. https://doi.org/10.1016/S01

[31] McAdam, M., \& Marlow, S. (2008). A preliminary investigation into networking activities within the university incubator. International Journal of Entrepreneurial Behavior and Research, 14(4), 219-241. 
[32] Campbell, C., Kendrick, R., Samuelson, D., 1985. Stalking the Latent Entrepreneur. Economic Development Review, Volume 3(2), pp. 43-48

[33] Campbell, C. (1988). Change Agents in The New Economy: Business Incubators and Economic Development. Cooperative Community Development Program, Hubert H. Humphrey Institute of Public Affairs, University of Minnesota.

[34] Campbell, C. (1989). Change Agents In The New Economy: Business Incubators And E. Economic Development Review, 7(2), 56.

[35] Costa-David, J., Malan, J., \& Lalkaka, R. (2002, April). Improving business incubator performance through benchmarking and evaluation: lessons learned from Europe. In 16th International Conference on Business Incubation, Toronto, Canada, April.

[36] Halim, F. (2020). Digital-Based Incubator Framework Modelling for University. International Journal of E-Entrepreneurship and Innovation (IJEEI), 10(1), 14-27.

[37] N. Somsuk and T. Laosirihongthong, "A fuzzy AHP to prioritize enabling factors for strategic management of university business incubators: Resource-based view," Technol. Forecasting Soc. Change, vol. 85, pp. 198-210, 2014. doi: 10.1016/j.techfore.2013.08.007.

[38] J. Hausberg and S. Korreck, "Business incubators and accelerators: A co-citation analysis-based, systematic literature review," J. Technol.Transfer, vol. 45, pp. 151-176, 2020. doi: 10.1007/s10961-018-9651-y.

[39] To"tterman, H., \& Sten, J. (2005). Start-ups - Business incubation and social capital. International Small Business Journal, 23(5), 487-511. https://doi.org/10.1177/0266242605055909.

[40] Hallam, C. R., \& DeVora, N. (2009, August). Technology-based business incubation: A study of the differences and similarities between private, university, and government incubation. In PICMET'09-2009 Portland International Conference on Management of Engineering \& Technology (pp. 1875-1887). IEEE.

[41] McAdam, M., Galbraith, B., McAdam, R., \& Humphreys, P. (2006). Business processes and networks in university incubators: A review and research agendas. Technology analysis \& strategic management, 18(5), 451-472.

[42] Sarwono, R., \& Trisetyarso, A. (2017, May). Business incubator indicator service performanceA systematic literature review. In 2017 International Conference on Applied Computer and Communication Technologies (ComCom) (pp. 1-5). IEEE.

[43] Mian, S. A. (1996). Assessing value-added contributions of university technology business incubators to tenant firms. Research Policy, 25(3), 325-335. doi:10.1016/0048-7333(95)00828-4

[44] Peters, L., Rice, M., \& Sundararajan, M. (2004). The role of incubators in the entrepreneurial process. Journavanderl of Technology Transfer, 29(1), 83-91.

[45] Chandra, A., He, W., \& Fealey, T. (2007). Business Incubators in China: A financial services perspective. Asia Pacific Business Review, 13(1), 67-77.

[46] Chandra, A., \& Chao, C. A. (2016). Country context and university affiliation: a comparative study of business incubation in the United States and Brazil. Journal of technology management \& innovation, 11(2), 33-45.

[47] Bruneel, J., Ratinho, T., Clarysse, B., \& Groen, A. (2012). The Evolution of Business Incubators: Comparing demand and supply of business incubation services across different incubator generations. Technovation, 32(2), 110-121.

[48] Vanderstraeten, J., \& Matthyssens, P. (2012). Service-based differentiation strategies for business incubators: Exploring external and internal alignment. Technovation, 32(12), 656-670. 
Vol. 3, No. 1, August 2020

[49] Lee, S.S., \& Osteryoung, J.S. (2004). A comparison of critical success factors for effective operations of university business incubators in the United States and Korea. Journal of Small Business Management, 42(4), 418-426.

[50] Organisation for Economic Co-operation and Development (OECD) (1997), Technology Incubators: Nurturing Small Firms, Paris.

[51] Organisation for Economic Co-operation and Development (OECD) (2010), High-growth enterprises: What governments can do to make a difference, OECD studies on SMEs and entrepreneurship, OECD Publishing, Paris.

[52] Legner, C., Eymann, T., Hess, T., Matt, C., Böhmann, T., Drews, P., ... \& Ahlemann, F. (2017). Digitalization: opportunity and challenge for the business and information systems engineering community. Business \& information systems engineering, 59(4), 301-308.

[53] Rogers, D. (2016). The digital transformation playbook: Rethink your business for the digital age. Columbia Business School Publishing. New York: Columbia University Press.

[54] Loebbecke, C., \& Picot, A. (2015). Reflections on societal and business model transformation arising from digitization and big data analytics: A research agenda. The Journal of Strategic Information Systems, 24(3), 149-157.

[55] Bharadwaj, A., El Sawy, O., Pavlou, P., \& Venkatraman, N. (2013). Digital business strategy: Toward a next generation of insights. MIS Quarterly, 37(2), 471-482.

[56] Verhoef, P. C., Broekhuizen, T., Bart, Y., Bhattacharya, A., Qi Dong, J., Fabian, N., \& Haenlein, M. (2019). Digital transformation: A multidisciplinary reflection and research agenda. Journal of Business Research. https://doi.org/10.1016/j.jbusres.2019. 09.022 (in press).

[57] Wang, C.L. (2008), "Entrepreneurial orientation, learning orientation, and firm performance", Entrepreneurship Theory and Practice, Vol. 32 No. 4, pp. 635-657.

[58] Nguyen, T.H., Newby, M. and Macaulay, M.J. (2015), "Information technology adoption in small business: confirmation of a proposed framework", Journal of Small Business Management, Vol. 53 No. 1, pp. 207-227.

[59] Autio, E., Nambisan, S., Thomas, L. D. W., \& Wright, M. (2018). Digital affordances, spatial affordances, and the genesis of entrepreneurial ecosystems. Strategic Entrepreneurship Journal, 12(1), 72-95. https://doi.org/10.1002/sej.1266.

[60] Tilson, D., Lyytinen, K., \& Sørensen, C. (2010). Research commentary - digital infrastructures: The missing IS research agenda. Information Systems Research, 21(4), 748-759. https://doi.org/10.1287/isre.1100.0318.

[61] Eller, R., Alford, P., Kallmünzer, A., \& Peters, M. (2020). Antecedents, consequences, and challenges of small and medium-sized enterprise digitalization. Journal of Business Research, 112, 119-127.

[62] Gioia, D. A., Patvardhan, S. D., Hamilton, A. L., \& Corley, K. G. (2013). Organizational identity formation and change. Academy of Management Annals, 7(1), 123-193. https://doi.org/10.1080/19416520.2013.762225.

[63] Hinings, B., Gegenhuber, T., \& Greenwood, R. (2018). Digital innovation and transformation: An institutional perspective. Information and Organization, 28(1), 52-61. https://doi.org/10.1016/j.infoandorg.2018.02.004.

[64] Westerlund, M. (2020). Digitalization, Internationalization and Scaling of Online SMEs. Technology Innovation Management Review, 10(4).

[65] OECD (2017). Key issues for digital transformation in the G20. Berlin, Germany. Available at<https://www.oecd.org/g20/key-issues-for-digital-transformation-inthe-g20.pdf> 
[66] OECD (2016). Skills for a digital world: 2016 ministerial meeting on the digital economy background report (OECD Digital Economy Papers No. 250). Paris. https://doi.org/10.1787/5jlwz83z3wnw-en.

[67] Beliaeva, T., Ferasso, M., Kraus, S., \& Damke, E. J. (2019). Dynamics of digital entrepreneurship and the innovation ecosystem. International Journal of Entrepreneurial Behavior \& Research, 26(2), 266-284. https://doi.org/10.1108/IJEBR-06-2019-0397.

[68] Sousa, M. J., \& Wilks, D. (2018). Sustainable skills for the world of work in the digital age. Systems Research \& Behavioral Science, 35(4), 399-405. https://doi.org/10.1002/sres. 2540.

[69] North, K., Aramburu, N., \& Lorenzo, O. J. (2019). Promoting digitally enabled growth in SMEs: a framework proposal. Journal of Enterprise Information Management.

[70] Enders, A., and T. Jelassi. 2000. "The Converging Business Models of Internet and Bricks-andMortar Retailers.” European Management Journal 18(5):542-550.

[71] Sherman, H., Chappell, D.S., 1998. Methodological Challenges in Evaluating Business Incubators Outcomes. Economic Development Quarterly, Volume 12(4), pp. 313-321

[72] Colombo, M.G., Delmastro, M., 2002. How Effective Are Technology Incubators? Evidence from Italy. Research Policy, Volume 31(7), pp. 1103-1122

[73] Haapasalo, H., Ekholm, T., 2004. A Profile of European Incubators: A Framework for Commercializing Innovations. International Journal of Entrepreneurship and Innovation Management, Volume 4, pp. 248-270

[74] Pena, I., 2004. Business Incubation Centers and New Firm Growth in the Basque Country. Small Business Economics, Volume 22(3-4), pp. 223-236

[75] Bøllingtoft, A., Ulhøi, J.P., 2005. The Networked Business Incubator-leveraging Entrepreneurial Agency? Journal of Business Venturing, Volume 20(2), pp. 265-290

[76] Chandra, A., Chao, C.A., 2011. Growth and Evolution of High-technology Business Incubation in China. Human Systems Management, Volume 30(1-2), pp. 55-69

[77] Hughes, M., Ireland, R.D., Morgan, R.E., 2007. Stimulating Dynamic Value: Social Capital and Business Incubation as a Pathway to Competitive Success. Long Range Planning, Volume 40(2), pp. $154-177$

[78] Etzkowitz, H. (2002). Incubation of incubators: innovation as a triple helix of university-industrygovernment networks. Science and Public Policy, 29(2), 115-128.

[79] Barbero, J.L., Casillas, J.C., Ramos, A., \& Guitar, S. (2012). Revisiting incubation performance: How incubator typology affects results. Technological Forecasting and Social Change, 79(5), 888-902.

[80] Todorovic, Z.W., \& Suntornpithug, N. (2008). The multi-dimensional nature of university incubators:capability/resource emphasis phases. Journal of Enterprising Culture, 16(4), 385-410. 